\title{
How Corporate Social Responsibility Indicators Influence Organization Identification? The Perspective of Labor Relations
}

\author{
Ya-Chin Kang*, Chia-Yu Chiu \\ Department of Labor Relations, Chinese Culture University (PCCU), Taiwan \\ Email: *kangyaji@gmail.com, s1818607@hotmail.com
}

How to cite this paper: Kang, Y.-C. and Chiu, C.-Y. (2016) How Corporate Social Responsibility Indicators Influence Organization Identification? The Perspective of Labor Relations. iBusiness, 8, 61-69. http://dx.doi.org/10.4236/ib.2016.84007

Received: August 14, 2016

Accepted: November 7, 2016

Published: November 10, 2016

Copyright $\odot 2016$ by authors and Scientific Research Publishing Inc. This work is licensed under the Creative Commons Attribution International License (CC BY 4.0).

http://creativecommons.org/licenses/by/4.0/ (c) (i) Open Access

\begin{abstract}
This study examined the relationship between corporate social responsibility and the job-seekers' viewpoint of organizational identification. First, corporate social responsibility indicators were constructed by reviewing, analyzing, and classifying the content of the CSR website in Taiwan. The CSR indicators of industrial relations were integrated. The questionnaire was conducted to investigate the interviewees' on the opinions of CSR and organizational identification (OI). It is intended that the results of these studies could be helpful in enhancing companies' identification with corporate social responsibility, and be further applicable in the design of corporate recruitment activities. Conclusions are as followed: 1) corporate social responsibility is predicted from three important dimensions: labor and social care, corporate operations, and environmental protection. 2) A total of 35 corporate social responsibility indicators are established for evaluation the industrial relationship of companies in Taiwan, which could be used as reference by both job seekers and companies. 3) The job seekers' organization identification with corporate social responsibility indicators is related to various variables, such as gender, age, educational background, profession field, and current employment status.
\end{abstract}

\section{Keywords}

Corporate Social Responsibility, Organization Identification, Labor Relations

\section{Introduction}

In recent years, greater attention has been paid to corporate social responsibility. Social responsibility has positive influence on corporate reputation [1]. When a company lives up to its social responsibility, it would create positive influences on its 
corporate reputation, which would help the company to maintain its competitive advantage [2] [3]. These studies show that a company's pursuit of corporate social responsibility should be more than just the international trade of attaching greater importance to social responsibility, but more as a way to build up competitive advantages in the market. Past studies were focused on the perspective of managerial status role, such as CEO [4], or stakeholders [5]. These works have shown that countries' institutional environments including related regulations, societal knowledge, and social norms can influence firms' adoption of CSR practices [6]. This study attempted to investigate the job seekers' organization identification whether influence by their CSR when applying for a job.

\section{Research Purpose}

"Talent" is a core element in the development of companies, and how to retain core employees and recruit potential talents are essential to the core work of the human resources department. This study examines the influence on a company's recruitment activities, as imposed by the degree of importance it gives to social responsibility. The research purposes are listed as follows: 1) analyze the components of corporate social responsibility and construct corresponding indicators using text mining; 2) understand the influential factors on company integration of corporate social responsibility in its structured interviews; 3 ) understand the evaluative factors on how organizational identification could be enhanced using the above mentioned recruitment model.

\section{Literature Review}

\subsection{Corporate Social Responsibility}

In new economic era, enterprises must undertake the corporate social responsibility (CSR) to promote their competitive advantage. Thus, it is getting more and more important to disclose CSR [7]. There is a theoretical model to describe and explain variation in corporate governance of identifying the social relations that interests corporation serve, and the allocation of rights and responsibilities among corporate stakeholders [8]. Corporate social responsibility should include economic responsibility, legal responsibility, ethical responsibility, and philanthropic responsibility. And, there is offered a corporate social responsibility pyramid model, which listed the following: economic, legal, ethical, and philanthropic responsibilities, which constitute the overall social responsibility of a company [9]. CSR can be a response to leaders' personal needs for attention and image reinforcement [10] and affect organizational financial performance [11]. Labor is seen by organizations as a significant component for advancing CSR, and the position of labor as a stakeholder is much more an issue. According to the case study in Australia bank, the CSR indicator emphasis were to be on environmental and financial sustainability with lesser importance placed on dimensions of workplace management and accompanying employee relations approaches [12]. But, in the highly-unemployment situation of economic environment, it seems to be problematic. 


\subsection{Organizational Identification}

Organizational identification referred to "whether an employee saw himself or herself as a member of the organization, thus, identifying with the organization's mission, values, and goals, and integrating the interests of the organization into the various management decision-making processes" [13]. Organizational identification is also defined as an employee's identification with the company's ideologies, sense of belonging, and a cognitive link between the definition of the organization and the definition of oneself [14]. In recent years, many scholars have argued that organizational identification is more than a concept reflecting changes in the environment, it is also useful in accounting for the differences in work motivation and work performance for employees at different levels. Organizational identification could contribute to internal cohesion and external expansion, and is divided into three levels: identification with oneself, identification with the group, and identification with the organization [15] [16] [17]. Studies that focus on organizational identification have spanned the two fields of organizational behavior and marketing.

As the concept of organizational identity continues to develop, many researchers have noted its role in strategic management. In maintaining the competitive advantage of organizations in particular, organizational identity seems to be even more important [18] [19] [20]. Identity and identification were two powerful elements at the initial development of an organization, and were highly meaningful and somewhat strategic in the efforts to build a practical team or socialized entity [21].

In brief, identity and identification are fundamental to the building of organizations through organizational behaviors. If the gap between the perceived "organizational identity" of the members in an organization and their self-identities was too great, disidentification would occur, ultimately leading to negative behaviors [22]. There was argued that when an individual found the organizational identity attractive, their identification with the organization would be affected [23]. From these studies, it is clear how decisive an influence organizational identity could impose on organizational identification. For the purpose of management, therefore, organizational identification is a very important concept, and is more important than organizational commitment, as only employees that identify strongly with the organization will make decisions that comply with the interests of the organization, even when unsupervised [13].

In summary, organizational identification is comprised of the following components: 1) the employees' value the honor to serve the organization as its members, 2) a win-win relationship between the organization's development and one's career, 3) the employees willingness to continue serving the organization in the future, 4) the employees' willingness to go all out for their work, 5) the employees' willingness to stand up to new challengers in their work.

Although it was possible for an organization to affect its applicant attraction by conducting recruitment activities, even more influential was the applicant's imagination of the corporate reputation before interview [24]. It has also suggested that corporate image was usually the utmost priority for an applicant in their decision making [25]. In 
addition to their knowledge of the limited job information available to them, applicants often depend on the relevant events or behaviors of the organization to gain insight into their future work environment [26].

In summary, while corporate social responsibility influences recruitment to some extent; there are no studies conducted to determine what these influences actually are, or how organizational identification could be measured in recruitment activities. Therefore, this study proposed the hypothesis that, the integration of corporate social responsibility into recruitment activities has positive influence on organizational identification, and then, conducts analysis to validate the relationship.

\section{Methodology}

The conceptual framework of this study was created by reviewing relevant literature in a continuous manner and integrating relevant studies at home and abroad. Based on the concept of corporate social responsibility, this study attempts to understand the concept factors that influence organizational identification during structured interviews in the course of recruitment activities.

In order to achieve the research purposes of this study, a questionnaire was independently designed and prepared after literature review. The questionnaire was then distributed among the companies involved in this case study. After collecting the questionnaires, the valid data were input into the system for the purpose of statistical analysis.

With the concept of corporate social responsibility (CSR) as the basis, after the structured interview system was integrated, a research structure was established for this study, and the research hypotheses were developed and variables were defined according to this research structure. Then, a questionnaire was designed, as based on the recruitment procedures of the companies involved in this case study, in order to understand the interviewees' opinions of corporate identification (Figure 1).

This study developed a questionnaire by referring to the various variables as the constructs of corporate social responsibility and organizational identification. In order to explore the CSR in labor relations, this study collected the graduated students of labor relations in March $2016(\mathrm{~N}=120)$. There were 38 valid questionnaire respondents were collected (response rate $31.67 \%$ ). Table 1 shows the sampling distribution.

\begin{tabular}{|c|c|c|}
\hline $\begin{array}{l}\text { Construct the corporate } \\
\text { social responsibility } \\
\text { indicators }\end{array}$ & $\begin{array}{l}\text { Establish the content for } \\
\text { the structure interview }\end{array}$ & $\begin{array}{c}\text { Analyze relationship between } \\
\text { CSR and organizational } \\
\text { identification }\end{array}$ \\
\hline $\begin{array}{l}\text { Analyze organization cases } \\
\text { through reviewing } \\
\text { information disclosure } \\
\text { report, and classify the } \\
\text { texts on the websites }\end{array}$ & $\begin{array}{l}\text { Integrate the corporate } \\
\text { social responsibility } \\
\text { indicators into the } \\
\text { establishment of the } \\
\text { procedures and contents }\end{array}$ & $\begin{array}{c}\text { Analyze the impacts on } \\
\text { organizational identification } \\
\text { when corporate social } \\
\text { responsibility indicators } \\
\text { are integrated into labor } \\
\text { relations viewpoint }\end{array}$ \\
\hline
\end{tabular}

Figure 1. Research framework. 
Table 1. The demographic distribution of responses.

\begin{tabular}{|c|c|c|c|c|c|}
\hline Variable & Category & $\begin{array}{l}\text { Responses } \\
\text { (percentage) }\end{array}$ & Variable & Category & $\begin{array}{l}\text { Responses } \\
\text { (percentage) }\end{array}$ \\
\hline \multirow{3}{*}{ Gender } & Male & $18(47.4 \%)$ & & None & $2(5.3 \%)$ \\
\hline & Female & $20(52.6 \%)$ & & Once & $10(26.3 \%)$ \\
\hline & & & Job seeking experience & Twice & $12(31.6 \%)$ \\
\hline Age & $21-30$ & $31(81.6 \%)$ & & Three times & $4(10.5 \%)$ \\
\hline \multirow{3}{*}{$\begin{array}{l}\text { Educational } \\
\text { background }\end{array}$} & \multirow{3}{*}{$\begin{array}{c}\text { College/vocational college } \\
\text { Master/PhD }\end{array}$} & \multirow{3}{*}{$\begin{array}{l}29(76.3 \%) \\
9(23.7 \%)\end{array}$} & \multirow{3}{*}{ Current employment status } & Incumbent & $28(73.7 \%)$ \\
\hline & & & & Student & $3(7.9 \%)$ \\
\hline & & & & Others & $7(18.4 \%)$ \\
\hline $\begin{array}{l}\text { Latest job seeking } \\
\text { period }\end{array}$ & Within 3 months & $8(21.1 \%)$ & Profession background & Business & $18(47.4 \%)$ \\
\hline
\end{tabular}

\section{Results}

Based on the literature review, indicators reflective of identification with corporate social responsibility include 35 indicators on the three levels of labor and social ethics, corporate operations, and environmental protection (Table 2).

\subsection{Gender, Age and Educational Background Analysis}

\section{1) Gender}

According to analysis based on gender differences, significant differences are seen only in the four indicators of "health and safety", "product and service labeling", "diversity and equal opportunities", and "non-discrimination policies" on the level of labor and social care, meaning that women tend to attach greater importance to these indicators, as compared to men.

\section{2) Age}

According to analysis based on age differences, significant differences are seen in various indicators, such as "employee training (training and education)", "coordination of industrial relations", "contribution to the community (social participation)", "safety and health", "workplace environment (lighting, ventilation, comfort)", "employee health and care", "equal pay for equal work", "public policies", "human rights appeal mechanism", "customer privacy (product liability)", and "diversity and equal opportunities". On the level of corporate operations, significant differences are seen in "employment opportunities", meaning that people aged 21 - 30 attach more importance to this indicator, as compared to those aged between 31 and 40 or above.

\section{3) Educational background}

According to analysis based on the differences in educational background, significant differences are seen in various indicators, such as "union development", "workplace environment (lighting, ventilation, comfort)", "corporate governance", "equal pay for 
Table 2. Identification with corporate social responsibility indicators.

\begin{tabular}{|c|c|}
\hline Category & Indicator \\
\hline 1. Labor and social ethics & $\begin{array}{l}\text { 1. Labor benefits policies } \\
\text { 2. Employee training (training and education) } \\
\text { 3. Coordination of industrial relations } \\
\text { 4. Union development } \\
\text { 5. Contribution to the community (social participation) } \\
\text { 6. Safety and health } \\
\text { 7. Workplace environment (lighting, ventilation, comfort) } \\
\text { 8. Employee health and care } \\
\text { 9. Employment } \\
\text { 10. Compliance with relevant labor regulations } \\
\text { 11. Corporate governance } \\
\text { 12. Equal pay for equal work } \\
\text { 13. Public policies } \\
\text { 14. Employee appeal mechanism } \\
\text { 15. Human rights appeal mechanism } \\
\text { 16. Customer privacy (product liability) } \\
\text { 17. Product and service labeling } \\
\text { 18. Freedom to organize labor unions and societies } \\
\text { 19. Diversity and equal opportunities } \\
\text { 20. Non-discrimination policies }\end{array}$ \\
\hline 2. Corporate operations & $\begin{array}{l}\text { 1. Operational management } \\
\text { 2. Competitive advantages } \\
\text { 3. Employment opportunities } \\
\text { 4. Economic benefits (a reasonable benefit-cost ratio between business output and input) } \\
\text { 5. Market share } \\
\text { 6. Corporation between the manufacturer and suppliers } \\
\text { 7. Economic influence } \\
\text { 8. Financial transparency }\end{array}$ \\
\hline 3. Environmental protection & $\begin{array}{l}\text { 1. Climate change policies } \\
\text { 2. Reduction and management of industrial wastes } \\
\text { 3. Use of green energy } \\
\text { 4. Environmental quality protection during the manufacturing process (e.g.: air, lighting, etc.) } \\
\text { 5. Environmental protection during the logistics process for a product (e.g.: air, noise, etc.) } \\
\text { 6. Compliance with relevant environmental protection rules and regulations } \\
\text { 7. Supply chain sustainability }\end{array}$ \\
\hline
\end{tabular}

equal work", and "freedom to organize labor unions and societies" on the level of labor and social care, meaning that college and vocational college graduates attach more importance to these indicators than those with master's or doctoral degrees.

\subsection{Profession Background, Previous Job Seeking Experience, Latest Job Seeking Period and Current Employment Status Analysis}

\section{1) Profession background}

According to analysis based on the differences in professional background, signifi- 
cant differences are seen in two indicators: "compliance with relevant labor regulations" on the level of labor and social care, and "cooperation between the manufacturer and suppliers" on the level of corporate operations. The Scheffe post hoc test found that people with a professional background in management, business, and tourism tend to identify more with the indicator of "compliance with relevant labor regulations", as compared to those from electrical engineering, computer science, and technological schools. In terms of the indicator of "cooperation between the manufacturer and suppliers", people with a professional background in humanities, sociology, and law tend to show greater identification, as compared to those from management, business, and tourism schools.

\section{2) Previous job seeking experience}

According to analysis based on the differences in previous job hunting experience, no significant differences are seen in any of the indicators.

\section{3) Latest job seeking period}

According to analysis based on the differences in the date of the latest job application, no significant differences are seen in any of the indicators.

\section{4) Current employment status}

According to analysis based on the differences in the current employment status, significant differences are seen in four indicators: "labor benefits policies", "employee health and care", "corporate governance", and "equal pay for equal work". The Scheffe post hoc test found that people in the category of others (including job seekers and housewives) tend to identify more with the indicator of "labor benefits policies", as compared to students; people at work tend to identify more with the indicators of "employee health and care", "corporate governance", and "equal pay for equal work", as compared to students, as do people in the category of others.

\section{Conclusions and Suggestions}

The revision indicators of the CSR from the perspective of labor relations show the relevance of organization identification in the graduated students in Taiwan case. The employees' labor right and work value are still struggling for the balance of corporate' operation and labor equality. It is therefore necessary to extend the interest on labor relations issues among CSR area in different sectors, such as students/graduates, so that society can expand a reality sense of commerce and management context. In this study, CSR was revised to three issues: labor and social care, corporate operations, and environmental protection. These topics still have to face the economic challenges. The importance of the labor and social care, corporate operations, and environmental protection in the quality indicators of CSR has not been accomplished. Suggestion for further research for the samples is applied for jobs to understand their CSR and OI perception by in-depth interview. There will be helpful for us to strengthen the retain intention of new staffs in organization, especially when they change roles to become the part of organization. There will still expand the culture, commitment, and leadership issues to be further explored by qualitative research approach as well. 


\section{References}

[1] Morf, D.A., Schumacher, M.G. and Vitell, S.J. (1999) A Survey of Ethics Officers in Large Organizations. Journal of Business Ethics, 20, 265-271. http://dx.doi.org/10.1023/A:1006000131803

[2] Zairi, M. and Peters, J. (2002) The Impact of Social Responsibility on Business Performance. Managerial Auditing Journal, 17, 174-178. http://dx.doi.org/10.1108/02686900210424312

[3] Brammer, S. and Millington, A. (2005) Corporate Reputation and Philanthropy-An Empirical Analysis. Journal of Business Ethics, 61, 29-44.

http://dx.doi.org/10.1007/s10551-005-7443-4

[4] Agle, B.R., Mitchell, R.K. and Sonnenfeld, J.A. (1999) Who Matters to CEOs? An Investigation of Stakeholder Attributes and Salience, Corporate Performance and CEO Values. Academy of Management Journal, 42, 507-525. http://dx.doi.org/10.2307/256973

[5] Berman, S., Wicks, A., Kotha, S. and Jones, T. (1999) Does Stakeholder Orientation Matter? The Relationship between Stakeholder Management Models and Firm Financial Performance. Academy of Management Journal, 42, 488-506. http://dx.doi.org/10.2307/256972

[6] Aguinis, H. and Glavas, A. (2012) What We Know and Don't Know about Corporate Social Responsibility: A Review and Research Agenda. Journal of Management, 38, 932-968. http://dx.doi.org/10.1177/0149206311436079

[7] Lin, W.L. and Fu, C.J. (2011) The Disclosure of Corporate Social Responsibility on the Value-Relevance of Accounting Information: An Empirical Analysis of the Electronic Industry in Taiwan. Commerce and Management Quarterly, 12, 209-229.

[8] Aguilera, R.V. and Jackson, G. (2003) The Cross-National Diversity of Corporate Governance: Dimensions and Determinants. Academy of Management Review, 28, 447-465.

[9] Carroll, A.B. (1991) The Pyramid of Corporate Social Responsibility: Toward the Moral Management of Organizational Stakeholders. Business Horizons, 34, 39-48. http://dx.doi.org/10.1016/0007-6813(91)90005-G

[10] Petrenko, O.V., Aime, F., Ridge, J. and Hill, A. (2015) Corporate Social Responsibility or CEO Narcissism? CSR Motivations and Organizational Performance. Strategic Management Journal, 1-18.

[11] Ramchander, S., Schwebach, R.G. and Staking, K. (2012) The Informational Relevance of Corporate Social Responsibility: Evidence from DS400 Index Reconstitutions. Strategic Management Journal, 33, 303-314. http://dx.doi.org/10.1002/smj.952

[12] Suzanne Young, S. and Thyil, V. (2009) Governance, Employees and CSR: Integration Is the Key Tounlocking Value. Asia Pacific Journal of Human Resources, 47, 39-57. http://dx.doi.org/10.1177/1038411109105440

[13] Miller, J., Job, D. and Vassilev, V. (2000) Principles in the Evolutionary Design of Digital Circuits-Part I. Genetic Programming and Evolvable Machines, 1, 7-36. http://dx.doi.org/10.1023/A:1010016313373

[14] Dutton, J.E., Dukerich, J.M. and Harquail, C.V. (1994) Organizational Images and Member Identification. Administrative Science Quarterly, 39, 239-263. http://dx.doi.org/10.2307/2393235

[15] Golden-Biddle, K. and Rao, H. (1997) Breaches in the Boardroom: Organizational Identity and Conflicts of Commitment in a Nonprofit Organization. Organizational Science, 8, 593611. http://dx.doi.org/10.1287/orsc.8.6.593

[16] Elsbach, K.D. and Bhattacharya, C.B. (2001) Defining Who You Are by What You're Not: 
Organizational Misidentification and the National Rifle Association. Organization Science, 12, 393-413. http://dx.doi.org/10.1287/orsc.12.4.393.10638

[17] Ellemers, N., Gilder, D.D. and Haslam, S.A. (2004) Motivating Individuals and Groups at Work: A Social Identity Perspective on Leadership and Group Performance. Academy of Management Review, 29, 459-478.

[18] Stimpert, J.L., Gustafason, L.T. and Yolanda, Y. (1998) Organizational Identity with the Strategic Management Conversation: Contribution and Assumption. In: Whetten, D.A. and Godfrey, P.C., Eds., Identity in Organizations, Thousand Oaks, 83-98. http://dx.doi.org/10.4135/9781452231495.n4

[19] Scott, S.G. and Lane, V.R. (2000) A Stakeholder Approach to Organizational Identity. Academy of Management Review, 25, 43-62.

[20] Fiol, C.M. (2001) Revisiting an Identity-Based View of Sustainable Competitive Advantage. Journal of Management, 27, 691-699. http://dx.doi.org/10.1177/014920630102700606

[21] Albert, S., Ashforth, B.E. and Dutton, J.E. (2000) Organizational Identity and Identification: Charting New Waters and Building New Bridges. Academy of Management Review, 25, 13 17. http://dx.doi.org/10.5465/AMR.2000.2791600

[22] Bhattacharya, C.B., Rao, H. and Glynn, M.A. (1995) Understanding the Bond of Identification: An Investigation of Its Correlates among Art-Museum Members. Journal of Marketing, 59, 46-57. http://dx.doi.org/10.2307/1252327

[23] Dukerich, J.M. and Golden, B.R. (2002) Beauty Is in the Eye of the Beholder: The Impact of Organizational Identification, Identity, and Image on the Cooperative Behaviors of Physicians. Administrative Science Quarterly, 47, 507-537. http://dx.doi.org/10.2307/3094849

[24] Powell, G.N. (1984) Effects of Job Attributes and Recruiting Practices on Applicant Decisions: A Comparison. Personnel Psychology, 37, 721-732. http://dx.doi.org/10.1111/j.1744-6570.1984.tb00536.x

[25] Ahlrichs, N.S. (2000) Competing for Talent: Key Recruitment and Retention Strategies for Becoming an Employer of Choice. Palo Alto, California, Davies-Black.

[26] Breaugh, J.A. (1992) Recruitment: Science and Practice. PWS-KENT, Boston.

Submit or recommend next manuscript to SCIRP and we will provide best service for you:

Accepting pre-submission inquiries through Email, Facebook, LinkedIn, Twitter, etc. A wide selection of journals (inclusive of 9 subjects, more than 200 journals)

Providing 24-hour high-quality service

User-friendly online submission system

Fair and swift peer-review system

Efficient typesetting and proofreading procedure

Display of the result of downloads and visits, as well as the number of cited articles

Maximum dissemination of your research work

Submit your manuscript at: http://papersubmission.scirp.org/

Or contact ib@scirp.org 